\title{
Bridging Gaps in Minimum Humanitarian Standards and Shelter Planning by Critical Infrastructures
}

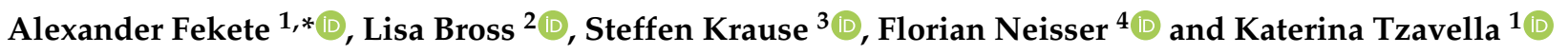 \\ 1 Institute of Rescue Engineering and Civil Protection, TH Köln-University of Applied Sciences, \\ 50679 Cologne, Germany; katerina.tzavella@th-koeln.de \\ 2 Wasserversorgung Rheinhessen-Pfalz GmbH, 55294 Bodenheim, Germany; 1.bross@wvr.de \\ 3 Department of Civil Engineering and Environmental Sciences, Bundeswehr University Munich, \\ 85577 Neubiberg, Germany; steffen.krause@unibw.de \\ 4 Fraunhofer Institute for Technological Trend Analysis (INT), 53879 Euskirchen, Germany; \\ florian.neisser@int.fraunhofer.de \\ * Correspondence: alexander.fekete@th-koeln.de
}

Citation: Fekete, A.; Bross, L.;

Krause, S.; Neisser, F.; Tzavella, K.

Bridging Gaps in Minimum

Humanitarian Standards and Shelter Planning by Critical Infrastructures. Sustainability 2021, 13, 849. https:// doi.org/10.3390/su13020849

Received: 3 December 2020 Accepted: 14 January 2021 Published: 16 January 2021

Publisher's Note: MDPI stays neutral with regard to jurisdictional clai$\mathrm{ms}$ in published maps and institutional affiliations.

Copyright: $(\odot 2021$ by the authors. Licensee MDPI, Basel, Switzerland. This article is an open access article distributed under the terms and conditions of the Creative Commons Attribution (CC BY) license (https:// creativecommons.org/licenses/by/ $4.0 /)$.

\begin{abstract}
Current agendas such as the Sendai Framework for Disaster Risk Reduction or the Sustainable Development Goals are demanding more integration of disaster risk management into other thematic fields and relevant sectors. However, certain thematic fields such as shelter planning and critical infrastructure have not been integrated yet. This article provides an analysis of minimum humanitarian standards contained in the well-known Sphere handbook. Gaps are identified for several critical infrastructure services. Moreover, guidance on how to derive infrastructure or lifeline needs has been found missing. This article analyses the missing service supply and infrastructure identification items and procedures. The main innovation is a more integrative perspective on infrastructure that can improve existing minimum humanitarian standards. It can guide the provision of infrastructure services to various types for different hazard scenarios, hence make humanitarian aid and shelter planning more sustainable in terms of avoiding infrastructure or lifeline shortages.
\end{abstract}

Keywords: critical infrastructure; risk management; disaster risk reduction; shelter planning; natural hazard

\section{Introduction}

In 2015 and 2016, 1.2 million refugees arrived in Germany [1]. Accommodating these numbers of arrivals, often at short notice, was an immense logistical and infrastructural task for the local authorities [2]. In many places, the existing infrastructure was not designed for many new residents. Therefore, due to a large number of people, temporary accommodations were built, and certain limitations of the infrastructure were accepted [3]. Since there exist no guidelines that encompass the breadth of water, sanitation, and other baseline services for humanitarian situations within Germany in the same detail as in international handbooks, the Sphere handbook was used by practitioners. The Foreign Office in Germany also uses the Sphere handbook as the main source for quality assurance and as a technical standard in its strategy paper for humanitarian aid in foreign countries [4]. However, the topic of infrastructure services is not limited to sheltering refugees since it also affects longer-term housing and integration. One of the social goals concerns the integration of the refugees into the local society [5]. For this purpose, the living standard of the refugees should be similar to that of the population in order to reduce the potential for conflict. Nevertheless, the provision of such a standard of living involves considerable financial and logistical effort [6].

Recent crises such as the refugee crisis in 2015 and 2016 have urged German local and national relief organisations and emergency managers to adjust their prepared measures and guidelines for emergency shelters. These measures and guidelines have been originally 
developed for civil protection and cold-war contexts, and have lately been adjusted to more recent contexts, such as hybrid warfare, mass incident management, natural hazards, critical infrastructure and others [7]. Still, in many local contexts, emergency managers were struggling, on the one hand, to erect shelters for refugees in 2015 quickly, and on the other hand to accompany the refugees and shelters so as to become temporal in the transition phase until construction of semi-permanent housing [8]. During this process, many emergency management organisations identified a lack of guidelines on modern aspects of sheltering refugees. While fire prevention and safety already were a huge topic in 2015 for Germany, the provision with water, energy and other utilities had to be managed, too. The provision of such supply infrastructure worked quite well for an industrialised country, such as Germany that was not facing any other disaster situation at the time. However, the update of emergency management for a mass influx of refugees gained higher interest and increased awareness. In this line, shelter guidelines such as the Sphere handbook were used by experienced emergency managers who had been active in foreign countries. The Sphere handbook was also used for lack of alternatives in the German language regarding minimum standards and guidance on different aspects of sheltering, not just housing, constructing, fencing and fire safety. However, a comprehensive manual was missing. Therefore, the Sphere handbook is reviewed in this article in order to identify areas that could be added and adjusted so as to fit it to the context of an industrialised country. Further, our goal is to provide insights on how to possibly extend the Sphere handbook and other standard guidelines in various contexts.

This article aims at underlining that this topic addresses a wider topic, too: how basic and critical infrastructure can better be integrated into international guiding documents and strategies. It is posited that the integrative potential of critical infrastructure is not yet fully developed in guiding documents and strategies such as the Sphere handbook, the Sendai Framework for Disaster Risk Reduction [9], or the Sustainable Development Goals [10]. The topic of critical infrastructure has the potential to combine different aspects of these concepts, as well as considering and bridging high-, middle- and low-income country contexts. This combination further needs more conceptual underpinning that this article aims to demonstrate, especially the topic of an existing standard and handbook for humanitarian contexts. While the Sphere handbook mainly points towards the response and recovery stage, the topic addressed in this article also bridges these stages with the preparedness stage by emphasising planning activities that include critical infrastructure assessments and avoidance of hazard zones into guiding concepts for planning and maintenance of shelters.

Critical infrastructure is increasingly recognised as being useful for planning in disaster risk reduction literature [11]. This article, however, identifies that in disaster relief and humanitarian aid, this is not yet the case. In most countries, the humanitarian disaster agenda and critical infrastructure run separately, and this misses important linkages. One important linkage is that this integration fills gaps in each agenda, such as critical infrastructure providing basic services for humanitarian situations of both affected and care-takers. Just as well, critical infrastructure has for too long focused only on technical measures and supplying the residential populations, while refugees and migrants are a large part of many societies worldwide. The option to integrate fields also applies to a wide range of global challenge and hazard contexts and their respective impact chains (Figure 1).

To examine this, a literature review is conducted on journal articles dealing with the topic of shelter and infrastructure, and related synonyms of critical infrastructure used more frequently in humanitarian contexts, such as lifelines.

Moreover, the focus of this article is narrowed down to demands, especially related to critical infrastructure services that assist emergency managers with the identification of suitable shelter planning designs for disaster-affected people. The topic of shelter planning is used since it integrates many fields relevant for humanitarian standards in the Sphere handbook, which is the main document analysed in-depth in this article. 


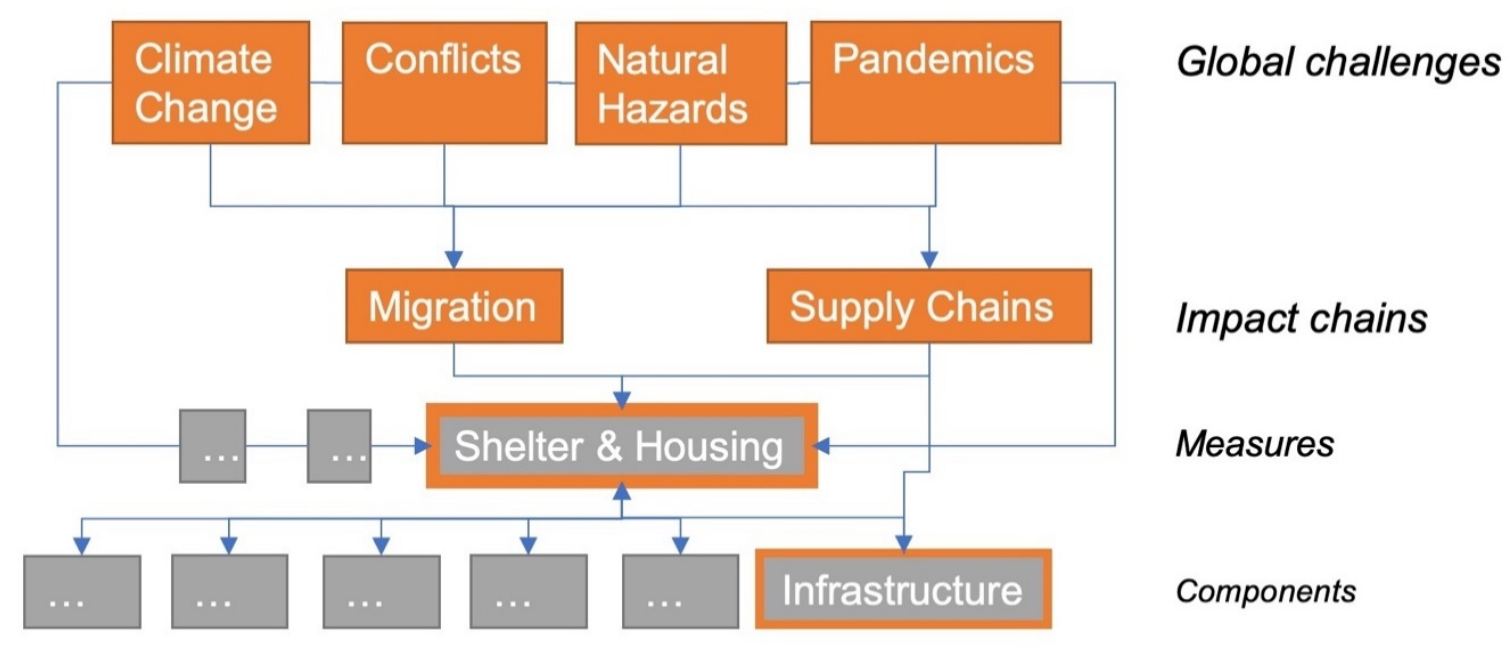

Figure 1. Shelter and housing are one major measure of dealing with global challenges, hazards and their impact chains, and infrastructure is one important component supporting this measure.

However, this article cannot cover all shelter types in all country or regional contexts. This article has been inspired by work conducted in the research project KIRMin on the topic of critical infrastructure in the context of an industrialised country, Germany [12]. Therefore, its scope is limited to industrialised countries, and expressly, to experience gained from research in Germany by the authors. Additionally, there is a distinction between emergency shelter, transitional (pending reconstruction) and permanent shelter in the literature [13], with this article aims to cover all phases. All phases are covered since the provision of infrastructure services such as water, food, information or health services are necessary for all phases of sheltering, even in those where emergency sheltering has turned into permanent housing. The target audience of this article is researchers and practitioners aiming to integrate different fields missing in conceptual guiding documents or frameworks such as the Sphere handbook, the Sendai Framework, or the Sustainable Development Goals. Another target group is the users of standards and guidelines such as the Sphere handbook for shelter planning, who also aim to observe critical infrastructure dependencies.

The main guiding research question for this article is:

- RQ: How can existing humanitarian standards and shelter planning be improved by an extension on the topic of critical infrastructure?

Further, the article will analyse the following specific research questions to break the main topic down:

- $\quad$ RQ 1: Why is there a gap within minimum supply standards concerning certain basic infrastructure services?

- $\quad$ RQ 2: Which role and characteristic do critical infrastructure play in the literature related to disaster risk management and shelter planning?

- $\quad$ RQ 3: Which role and characteristic do critical infrastructure play in a humanitarian standard guideline- the Sphere handbook?

- $\quad$ RQ 4: How can critical infrastructure become a cross-cutting topic for both industrialised and developing country contexts?

This article investigates the main research question by analysing the first and second specific research question (RQ1 and RQ2) by a brief literature review. In order to address RQ3, the Sphere handbook's latest edition is analysed in-depth on the aspect of how critical infrastructure is mentioned and which role and characteristics it bears. RQ4 is then addressed in a discussion chapter that draws on literature relating to critical infrastructure, sheltering and emergency management. 


\section{Brief State of the Art and Identification of the Gap within Minimum Supply Standards Concerning Certain Basic Infrastructure Services}

\subsection{Sheltering, Housing and Migration as a Background}

Sheltering and housing displaced populations are triggered by numerous societal and environmental conditions that often interact $[14,15]$. While it is a topic aggravating already existing precarious conditions in low-income countries, it is also a topic of middleand high-income countries. For example, the history of humanitarian aid stems from contexts of Europe and civil wars and involves several humanitarian and development aid developments following major crises such as natural hazards or armed conflicts $[16,17]$. Recent processes such as migration to Europe from the war that affected Syria and other countries in Asia, or migration from Africa due to economic and environmental conditions have sparked political debate and research in Europe and elsewhere [18,19]. Within this broad topic, one aspect is sheltering and housing for displaced populations $[20,21]$. The high number of migrants in 2015 fleeing civil war in Syria has been perceived by some in Europe as a "refugee crisis" first, due to the sudden demand to shelter thousands of refugees [18]. Later on, this process turned into a mid-term temporary housing challenge and has been perceived by the public and by certain political parties in Germany, for example, as a "migration crisis" [21]. It is still an on-going societal debate and includes long-term measures for the improvement of the conditions in countries of origin, but also border control and refugee camp management [19]. Safety and security of refugee camps and housing conditions have become pronounced by protests, violence and a burning camp in Moria, Greece [22,23]. The example of the current migration to Europe underlines the importance of humanitarian short-term as well as long-term planning of shelter and housing. Shelter and housing are an important part of providing infrastructure for refugees and migrants involving even more aspects of service provision.

\subsection{Infrastructure and Logistics within the Shelter Topic}

The overall topic of infrastructure services to humans affected by disasters connects the fields of humanitarian logistics or supply-chains [24,25] and (critical) infrastructure [26] with emergency or disaster shelter. Sheltering humans after natural or man-made disasters or crises increases globally due to migration, displacement or natural hazard impacts has reached staggering numbers [9]. A particular challenge for sheltering is not only to consider the logistics of supplying humans with essential services such as water, food or energy but also to guarantee human needs such as dignity and being safe from harm after having escaped the initial hazard impact $[27,28]$. Another challenge is the shelter location planning and the evacuation planning of an area or a hospital [29], due to the additional risk of losing lives during evacuation or sheltering, even in highly industrialised countries. For example, during Hurricane Katrina in the USA in 2005, it was a significant challenge to supply the people seeking refuge in the Super Dome football stadium [30] or the vast stream of people seeking refuge in the European Union in the years of 2015-2017. Further, studies on the evacuation after the earthquake, tsunami and nuclear power plant failure in Japan 2011 found that additional lives were lost during or after the evacuation [31]. But also in military contexts, such as the NATO Standardization Agreement (STANAG), infrastructure services and key commodities for survival can be found. These could be considered to inform standards for a more integrative crisis assistance framework.

\subsection{Basic Services and Critical Infrastructure in the Shelter Topic}

Sheltering disaster-affected people is already a challenge, but what if basic services such as water, food or energy fail, too? While there are ample studies on shelter construction, design [32,33] and general equipment demands including infrastructure and logistics provisioning [34], the aspect of potential failure of infrastructure is lacking. Critical infrastructure research is a field that developed in the aftermath of terror attacks in the USA. Even though it is a security topic, it has only recently found its way to connect with other areas of security research, such as human security, disaster risk reduction or disaster risk 
management [5,9]. Methodological approaches to critical infrastructure offer strategies and assessments, as well as conceptual components such as the 'criticality' to help prioritise infrastructure services for affected populations [11]. However, traditional shelter and disaster risk research often lack such methodologies for prioritisation. Specifically, studies on vulnerability and resilience, damage and loss and needs assessments contain aspects of a risks range and indications of hot spots, highest cost, highest vulnerability, or ex-post real case insights into which services were lacking and should be prioritised. However, the prioritisation of critical infrastructure services based on a comprehensive approach that matches stakeholder values, including societal values and norms, interests, goal and strategy selection, communication between stakeholders and affected people often lacks a similar methodological structure in many existing risks and resilience frameworks. A few studies dealing with critical infrastructure failure and crisis response planning have started to investigate emergency supply during long-lasting blackouts [35-38]. While these studies are conceptualised for specific critical infrastructure failure scenarios, it is crucial to analyse how existing shelter concepts take up such critical infrastructure failure aspects. However, there are only a few studies on minimum supply standards related to critical infrastructure for developed, industrialised countries [39].

\subsection{Minimum Standards in Humanitarian Aid}

In the field of humanitarian aid, the primary concern is often to establish minimum standards that are essential for survival or the prevention of adverse health effects. There are different approaches on how to derive the standards: bottom-up and top-down. The example of water supply illustrates the difference between the two approaches. A bottomup approach is used in the formulation of the vital water quantity. Here it is assumed that a minimum amount of water is required by the consumers, which is set as the lower limit. According to the Sphere handbook, the minimum standard in the area of humanitarian aid is 2.5 to 3 litres per person a day. The minimum standards under German law, however, are 15 litres per person a day [40].

In contrast, a top-down approach is used to determine acceptable losses in terms of water quantity or quality. This approach considers the technical minimum water quantities required to maintain a system. According to the German concept of civil defence, at least 50 litres per person a day are required to maintain the grid-based water supply. While humanitarian aid often relies on the grid-independent emergency water supply from a hygienic point of view, grid-bound supply is preferable [41,42], in regular circumstances as well as in crises. Grid-bound supply would require, for example, to determine the minimum amount of water that has to be fed to a water distribution system before low pressure leads to an intrusion of contaminated water by a pressure-driven hydraulic model instead of the more common demand-driven models [43]. The bottom-up approach is thus based on the requirements of the consumer. In contrast, the top-down approach is based on the requirements of the technical system, in this case, especially the water distribution network.

Beyond this, the interdependencies of critical infrastructure supply systems [44] should be taken into account for planning shelter locations. These are, in particular, interdependencies such as, e.g., control room personnel needing water to work during crises (for example, to manage an electricity supply problem) or needing heat on cold winter days. Moreover, some so-called "autonomous" electricity generation devices often rely on electric voltage from the electricity grid, or cannot start themselves without connection to it. An interdependency analysis points such possible weaknesses out and highlights the demand for adequate backups [12].

In previous studies, it was identified that existing critical infrastructure research and practice often sees infrastructure only as something purely technical, neglecting human staff, customers, and soft components, such as regulations and communication, which all make up the overall infrastructure service system [45]. Of course, this also includes the environment around these systems [11,46]. Besides assets and resources, generic 
components enable cross-sectoral, cross-infrastructure service provision and threshold settings (also named criticality): time, volume and quality. As one example, in a severe crisis, storage water may be the last resource available. However, even if lifelines were technically running, or water tanks were full, the question remains as to the duration of consumption and the acceptability of water quality. If the water were polluted, and no cooking power or purification chemicals were available, the water quality itself might be just as limiting as the amount of available water. This aspect can also be found in the WASH guidelines, which emphasises the need to take such generic thresholds, as well as the availability of ecosystem services (e.g., natural water resources), into account for shelter planning.

\subsection{Infrastructure as a Topic within the Broader Context of Disaster Risk Reduction}

The Sendai Framework for Disaster Risk Reduction by the United Nations [9] recently stressed the topic of 'critical infrastructure' as a backbone for the provision of vital services for humans, that, when interrupted, can gravely add to human losses or severe economic damage. Critical infrastructure is a term and research field that originated in a policy field in the context of terrorism in the USA in the 1990s [47]. The subject has, since then, propagated to include hazards such as natural hazards and has especially flourished in fields such as civil protection $[35,48,49]$. However, due to many recent disasters that involved a major aggravation of the impacts by interruption of important supply chains, the notion of vital, essential, or 'critical' infrastructure has found its way to be recognised even as a separate priority goal, in the Sendai Framework [50]. Over the years, the term critical infrastructure gained increasing importance in this area of the United Nations, as in comparison to previous guidelines, such as the Hyogo Framework or the Yokohama strategy [51,52]. In the field of critical infrastructure research, there are many more arguments to support its increasing importance in a more and more globalised world. The large variety of interdependencies between infrastructures can lead to cascading failure chains.

Additionally, the increasing dependency on electricity, digital information and transport logistics increase the vulnerability of critical infrastructure [44]. "Failure to respond carries human costs as well as significant economic and political risks. Food security, power blackouts and empty water taps are among the most immediate and sensitive public service issues for which societies hold governments accountable." [27]. Critical infrastructure is also of importance, as it contradicts common ideas; more development will solve the problem. This is the so-called vulnerability paradox that stresses that increasingly developed societies will be increasingly vulnerable due to their increasing blind reliance on the functionality of critical infrastructure [53]. This paradox also shows that there are two different vulnerabilities that need to be addressed: the vulnerability of (critical) infrastructures and the vulnerability of its dependent people [54].

\section{Investigation of the Role of Critical Infrastructure in the Sphere Handbook}

The Sphere handbook [28] is the global reference work for the humanitarian response that explicitly provides minimum standards for humanitarian purposes. It contains a separate chapter on shelter and settlement. In contrast, the remaining chapters focus on aspects of water supply, sanitation and hygiene promotion (WASH), food and various aspects important in humanitarian aid and its principles, notably, providing dignity to the people. Infrastructure and related services for accommodation standards are mentioned in its assessment framework (ibid., p. 11) and highlighted as one component supporting most humanitarian activities. The book is written by practitioners for practitioners and offers guidance and minimum standards, sometimes even with useful numerical thresholds and advice. However, there is no methodology on how to identify infrastructure services or people's priorities: the book rather states them as given by expert knowledge and provides literature sources. Therefore, the listed input and thresholds cannot be tested or adjusted easily on a scientific basis for other contexts. It has to be done by practice, which is excellent for its purpose, but lacking a methodology for transferability for the needs of different 
stakeholders [55]. While developed for humanitarian assistance, the content is also useful for extended domestic crises in the stage before calling for humanitarian or external aid.

While the WASH chapter is the most detailed on minimum thresholds, other chapters such as food and nutrition are less so; food and calories, for example, only lists one threshold (Sphere Association 2018, p. 198). The literature suggestions in this handbook on other minimum standards or thresholds are quite helpful. However, while the handbook addresses certain critical aspects of humanitarian assistance logistics quite well and stresses the needs of different types of (vulnerable) people, it still provides room for further extension of information suitable for the areas addressed in this article; critical infrastructure services and minimum supply needs (cf. Table 1).

Table 1. Sphere handbook minimum standards and related critical infrastructure services.

\section{Sectors Covered in the Sphere Handbook}

Details

\section{Food and Nutrition}

Health Services
Shelter

\section{Water/WASH}

\begin{tabular}{|c|c|c|c|c|}
\hline $\begin{array}{l}\text { Details provided on } \\
\text { minimum standards }\end{array}$ & Food and calories & $\begin{array}{l}\text { Percentages of } \\
\text { healthcare services, } \\
\text { inpatient bed numbers } \\
\text { and walking distances, } \\
\text { staff numbers, } \\
\text { medicine, Early } \\
\text { Warning and health } \\
\text { information reporting }\end{array}$ & $\begin{array}{l}\text { Minimum living space } \\
\text { Minimum clothing, } \\
\text { bedding, food and } \\
\text { cooking facilities }\end{array}$ & $\begin{array}{l}\text { Water containers of } \\
\text { drinking water and } \\
\text { water for everyday use, } \\
\text { and soap consumption, } \\
\text { personal hygiene, } \\
\text { water volume and } \\
\text { numbers of taps, water } \\
\text { quality, toilets, } \\
\text { healthcare settings for } \\
\text { disease treatment, and } \\
\text { differences of water } \\
\text { needs for different } \\
\text { facilities such as } \\
\text { schools, mobile clinics, } \\
\text { mosques }\end{array}$ \\
\hline $\begin{array}{l}\text { Missing aspects of } \\
\text { 'Critical Infrastructure' }\end{array}$ & $\begin{array}{l}\text { Food production and } \\
\text { supply chains, logistics, } \\
\text { food quality and } \\
\text { variety }\end{array}$ & $\begin{array}{l}\text { Unique services such as } \\
\text { fire burn treatment, } \\
\text { psychological support } \\
\text { for elderly and } \\
\text { children, etc. }\end{array}$ & $\begin{array}{l}\text { Supporting } \\
\text { infrastructure such as } \\
\text { electricity, cooling and } \\
\text { heating, accessibility, } \\
\text { tele-/communication } \\
\text { through mobile phone } \\
\text { charging kits, etc. }\end{array}$ & $\begin{array}{l}\text { Grid-based water } \\
\text { supply, (waste)water } \\
\text { discharge and } \\
\text { treatment }\end{array}$ \\
\hline
\end{tabular}

Upon analysing the minimum standards provided in the Sphere Handbook, it is apparent, when compared to the fields in critical infrastructure [56], that a great number of infrastructure services are not handled at all, namely:

- Contingency/disaster/emergency management, security

- Energy (electricity, heating, etc.)

- Finance and insurance

- Governance and administration, regulation

- Information and communication

- Transport and logistics

\section{Review of the Links between Critical Infrastructures, Shelter Planning and the Sendai Framework}

The Sendai Framework for Disaster Risk Reduction is a leading program in the field of disaster risk that covers fields such as emergency management and natural hazards, but also touches on fields such as humanitarian aid, development cooperation and many more. As early as March 2015, the relevance of critical infrastructures was emphasised by the United Nations in the Sendai Framework. One of the seven global core objectives is to 
ensure basic supply through critical infrastructure and to reduce disruptions. However, there are no other concrete suggestions for achieving the provision of basic services and reduction of interruptions under special circumstances such as emergency shelters.

A brief literature search has been conducted (i) using Google Scholar and (ii) using the Fraunhofer KATI (Knowledge Analytics for Technology and Innovation) tool to search through the Web of Science catalogue. Search terms and combinations thereof are documented to enable later studies conducting follow-up searches. First, literature related to the Sendai Framework is searched in combination with terms such as shelter and critical infrastructure. Second, key literature on shelter planning is searched, balancing between high usage and citations of some key articles and selecting some recent ones, too. The literature search in Google Scholar conducted on 12 May 2020, revealed over 9000 finds for the search term "Sendai Framework", and 1340 in combination with the term "critical infrastructure". In each search, patents and citations were excluded. The KATI search on 23 November 2020 resulted in 246 entries for "Sendai Framework" and nine entries in combination with "critical infrastructures" in the Web of Science collection. The combination of the terms "Sendai Framework" AND "shelter" revealed only 2690 hits with Google Scholar and three hits with KATI (Web of Science) by comparison.

With both approaches, no publication has been found to include both terms "critical infrastructure" and "Sendai Framework" in the title. It appears from a secondary analysis by reading abstracts, that critical infrastructure often is just one topic among many within the papers that include the "Sendai Framework" in the title. Using Google Scholar only one paper uses "Sendai Framework" and "infrastructure" in the title, but it is related to green infrastructure. No paper had "Sendai Framework" and "lifeline" in the title and only one included "lifeline" in the abstract (latter found using KATI). Additionally, no paper title bearing both "Sendai Framework" and "shelter" could be found with the implementation of the approaches. This lack of combination of the terms allows for the assumption that the topics of shelter and critical infrastructure together have hardly been addressed explicitly concerning the Sendai Framework in cited publications.

While the Sendai Framework intends to bridge themes and fields and foster more integration of approaches in many fields, it still misses certain emergent opportunities for additional integration; the integration of industrialised and developing country contexts, or stressing the integration of the topic of disaster relief with disaster reduction more prominently. It is commendable that the topic of infrastructure is considered in the Sendai Framework more prominently than before. Yet, it is one field where monitoring and reporting by indicators are still the second weakest (after international cooperation) in comparison to the other targets (https: / / sendaimonitor.undrr.org). On the other hand, the topic of infrastructure is quite underemphasised in other guiding documents. Therefore, it is laudable the fact that the Sendai Framework not only carries this topic as a target but also demands its monitoring by explicit indicators. For example, it is interesting to note that the Agenda for Humanity [57], as the outcome of the first Global Humanitarian Summit in Istanbul 2016, mentions the term infrastructure only once: "Schools, hospitals, places of worship and other critical civilian infrastructure must be spared from the military force and military use." It seems there is still a lot to be done to integrate topics such as humanitarian aid, disaster risk reduction and critical infrastructure protection.

\section{Discussion of Conceptual Gaps and Opportunities for a Cross-Cutting Topic for Both Industrialised and Developing Country Contexts}

The Sphere handbook was not written for the context of highly industrialised countries. Probably there was no original intention to regard infrastructure as anything other than to use a country's existing infrastructure as an aid to the provision of basic necessities. These minimum standards are not about repairing or augmenting infrastructure, or about the dependency on it or interdependencies between infrastructure supplies that might fail. However, this article argues that such minimum standards could be further expanded and benefit from additional information on this. In general, often no guiding criteria are used on how to include critical infrastructure into minimum humanitarian standards (such 
as minimum volume, quality or temporal availability). Therefore, minimum standards are randomly provided and in widely varying depths. As shown in the previous section, most requirements provide only minimum volume, but no time factors such as time required to regain functionality. Several quality aspects of food, treatment, shelter, etc., are missing as well. In general, the notion of dependence on other infrastructure such as medical treatment being dependent on delivery logistics, roads, water, electricity, etc., is lacking. Figure 2 shows an example of interrelations between the seven targets of the Sendai Framework with the sectors in the Sphere handbook, and selected Sustainable Development Goals. In addition, 'supply infrastructure' such as energy, information, roads/transportation and water could be an additional connecting topic between these frameworks. Certainly, there exist many more interrelations than shown Figure 2. It appears that much can be transferred and added from the field of critical infrastructure to expand the minimum standards of the Sphere handbook, too. 'Minimum supply standards' could consist of minimum levels of storage and supply to maintain basic functions for survival and avoidance of irreversible loss.

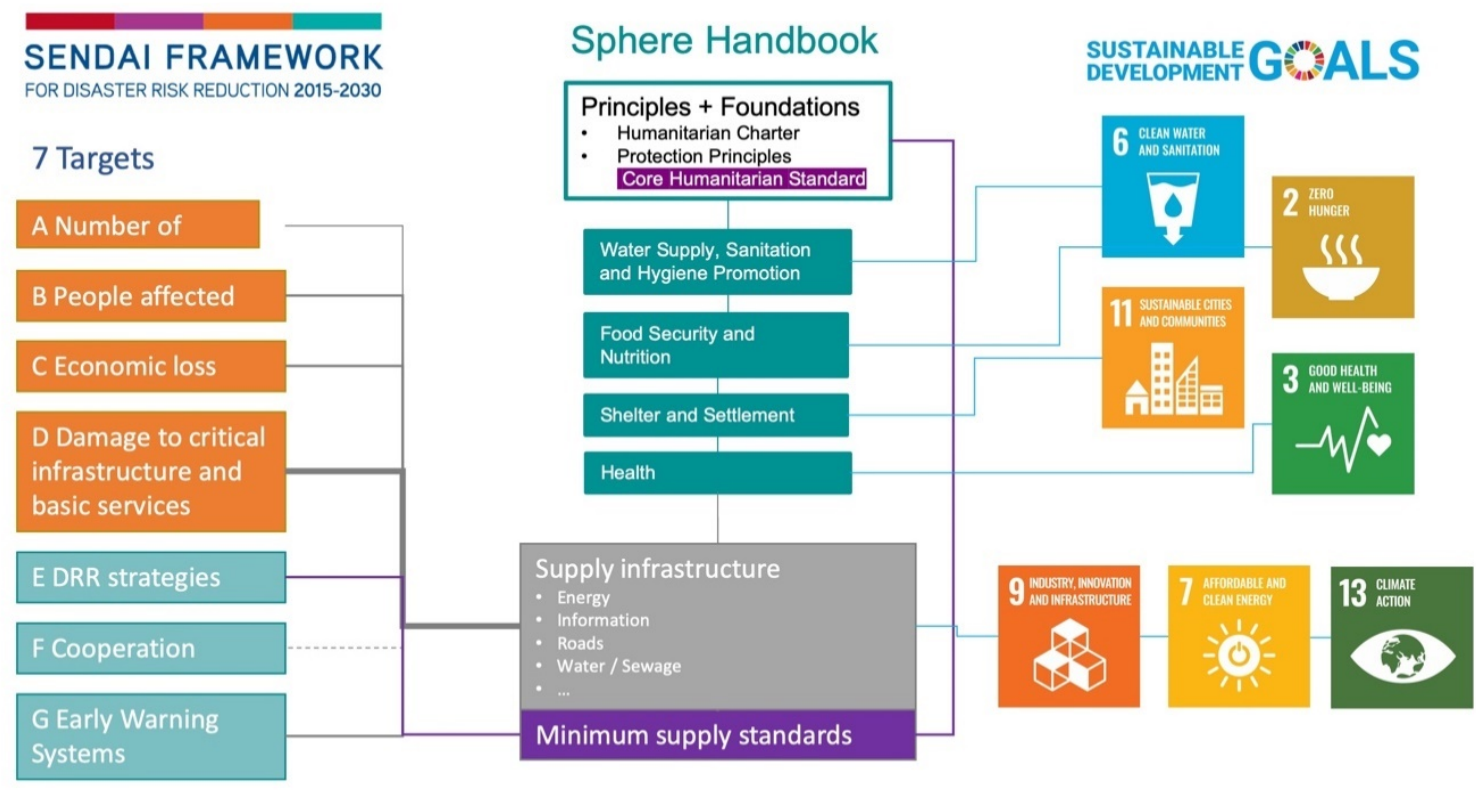

Figure 2. Possible interrelations between the Sendai Framework, the Sphere handbook and the Sustainable Development Goals on the topic of infrastructure.

\subsection{Connecting Different Notions of Security, Risk and Resilience}

When comparing the minimum standards provided in the Sphere handbook to the Human Security concept $[27,58]$, many security types are missing, namely 'economic', 'environmental' and 'political security', according to the United Nations/OCHA [59]. Other fields of security are addressed, but not in all their aspects, such as personal and community security, and only food and health security seem to be addressed in detail. Some other aspects may be added to future editions of the handbook. As an example, while the handbook lists advice on planning shelter or settlements in "areas with no or minimal known natural or man-made threats, risks and hazards" [28] (page 250) as a key indicator, it lacks detail on assessment methods and certain hazards. It is conceivable that methods for every possible aspect or activity are beyond the scope of this handbook. However, risk zonation [60] or avoidance of secondary hazards should be key aspects of a comprehensive shelter and settlement planning, and therefore, more guidance should be added. This lack of information impairs connectivity to spatial planning (and related fields of urban and territorial planning, including advanced planning), disaster risk management and emergency management. It must also be stressed that the Sphere handbook approach 
is more encompassing than critical infrastructure approaches. The latter often focus on infrastructure types relevant from the perspective of governments but usually lack basic services such as shelter, hygiene, personal and dignity needs. Again, it must be underlined that the Sphere handbook had probably no intention to emphasise any specific type of needs assessment or specific assessments such as hazard or risk zonation. However, this might be an important additional recommendation provided by the handbook in order to guide users to better identify risks in their shelter area.

Moreover, many studies seem to replace the term risk with the term resilience or simplify resilience into specific components: reduction, readiness, response and recovery (abbreviation used by original authors: 4R) that often overlap conceptually with risk or vulnerability components [61,62]. The explanatory power of criticality, which is a prioritisation step in a methodology towards saving time and resources in later stages of a range of risk analysis [63], is often overlooked in assessments that simply summarise pre-existing components such as redundancy, robustness, or duration under the umbrella of resilience.

Another conceptual gap is the lack of a thorough differentiation of damage depth of critical infrastructure failure. Often only complete failure is analysed, but system degradation or initially small incidents can be a critical problem. More distinction within degradation phases is needed, especially for planners and crisis responders. This distinction is especially important under the conceptual claim of the positive lens of resilience, i.e., at the reaction, recovery and transformation options rather than just damage depth and negative aspects of susceptibility or fragility under vulnerability. Planners and actors of crisis response and critical infrastructure operators such as hospitals, want to know how to obtain more planning time. Therefore, analysing degrees of critical infrastructure failure is essential to get a differentiated picture. Certain civil protection agencies are developing guidelines for emergency phases of critical infrastructure failure, such as minimum supply phases during electricity blackouts or water shortages $[36,42,64]$.

\subsection{Preparedness Stimulated by Critical Infrastructure Failures}

"Besides basic income and resources, the freedoms to enjoy essential health, basic education, shelter, physical safety, and access to clean water and clean air are vitally important" (Ogata-Sen 2003)

A considerable amount of research has been published on surveys identifying food storage preparedness of different populations [65,66], and general crisis preparedness [67]. However, there appears to be a lack of evidence of the effectiveness of disaster supply kits [68]. Studies on a broader range of supply services have emerged in recent years, including several disasters, such as blackouts [69] and critical infrastructure failures in the context of extreme events such as river floods [70]. Aspects of food security and shelter are affected negatively in the short- and long-term period due to such disasters, requiring humanitarian assistance [71], and efforts have been made, taking from the Sphere handbook (2018) and other literature, to identify food and security standards in humanitarian action [72]. Natural hazard events triggered research in the field of critical infrastructure focused on the preparedness capabilities of critical infrastructure stakeholders, operators, authorities and in fewer cases, people affected $[73,74]$. For example, in the case of the power outages of a winter event in the Münster region (Germany) in 2005 that lasted several days and affected up to 250,000 people [75,76]. Another example is a communication failure in 2006 that led to a pan-European blackout for (just) up to 90 mins [77]. Water outages, transportation interruptions of train tracks and train stations and disruption of other infrastructure also came into public focus due to river-floods in 2002 and 2013 [78-80]. But also, for developing country contexts, the provision of basic services is of key importance. 


\subsection{Shelter Planning Background and Focus}

Another gap that is meant to be addressed is the often-unspoken background drivers of planning and operating refuge and humanitarian-aid shelters. While there are humanitarian standards and related concepts for providing an overall human security frame, i.e., [27], there are different realities for how different shelter types are operated under different crisis types [81,82], or different trajectories of post-disaster shelter [83]. It is a context variable that is decisive on how basic conditions, human rights and humanitarian standards are put into practice. For example, emergency shelters established due to ethnic conflicts, are often operated differently from other contexts such as flooding. For instance, ethnic conflicts can result in shelter design treating certain ethnic groups differently in the quality of provision of basic services, dignity, etc., as compared to areas where 'only' floods occur (or any other natural hazard). Planning of shelter lifetimes is often not built on humanitarian ideals alone but is influenced by political as well as economic considerations.

In some cases, planning requires the installation of removable infrastructure only. Shortcomings of purely structural and technical shelter planning are known for overseeing perspectives of social, psychological, ethnic and many other aspects [84]. However, planning should still be advanced on awareness of dependency on infrastructure supply in a technical sense and aspects such as access of people, integration of civil society, infrastructure operators, local authorities, private contractors and many more stakeholders [85].

\subsection{Advancing Existing Risk Management Guidelines on Aspects of Resilience and Minimum Supply}

Based on the experience of the research project KIRMin in Germany, insights into demands on improving disaster risk management were obtained [12] Three findings are discussed here that help drive this improvement: (i) demands for the update of guidelines, (ii) methods to inform such a process with the prioritisation of actions and risk analyses and (iii) updates on the resilience and minimum supply aspects as a specific detail (Figure 3).

For the topic of shelters, different guidelines published by fire brigades or authorities responsible for civil protection are available for Germany, at the federal, state or municipal level. Typically, they contain advice on technical issues and resource demands that include numerical capacities that emergency management organisations such as fire brigades should possess. For example, the guideline for treatment care of 500 persons includes advice on the number of leaders, staff and helpers and a schematic plan on how different site places should be organised [86]. In most cases, such guidelines neither contain information about the needs of people being treated nor their social vulnerability, nor information regarding (inter-) dependencies of shelter types with critical infrastructure services. The guidelines also do not possess information about hazards or methods for deriving or calculating capacity numbers mentioned.

To update guidelines or start a process of developing a disaster risk management strategy for sheltering, it was found that a method to help structure decisions on how to prioritise actions is helpful, though often missing. The reason is the emerging variety of regulations, standards and differing guidelines by different ministries in Germany and the EU that make it difficult to keep track and manage them. Furthermore, this applies specifically to local municipalities or small companies. Thus, guidelines have been developed at the national level to guide the process of risk and crisis management, including risk analysis, by adding a method of prioritisation. This prioritisation conducts a criticality assessment before the risk analysis and helps to identify societal values at risk and the underlying priorities of different stakeholders [63]. A major challenge in adopting such methods to the regarded context is identifying the appropriate range of critical infrastructure elements and processes and the often-lacking collaboration of relevant stakeholders. Participatory processes were found helpful as well as methods helping to identify bottlenecks and thresholds [12]. It is also essential to compare the provided (numerical) thresholds to documents within civil protection and infrastructure operators' 
guidelines and standards. They often deviate widely in different local contexts, and realities challenge the application of standards such as those in the Sphere handbook [55,81,82].

While resilience concepts and assessments often are very holistic in their approach, the emergency and disaster managers often need more guidance regarding the initiation of actions. Therefore, it is argued that the different phases of a crisis should be broken down into full, partial and minimum supply, where minimum supply characterises the situation when only the last and most important functions can be maintained and saved from irreversible loss. The scientific literature in Germany is also scarce regarding minimum supply aspects that concern infrastructure services in extreme situations and demand a minimum supply. However, there are some first literature reviews [87] and a study regarding emergency water supply [39]. In the field of safety engineering, there also exists a flood risk-based accessibility assessment of refugee shelters for the city of Cologne (Germany) [88].

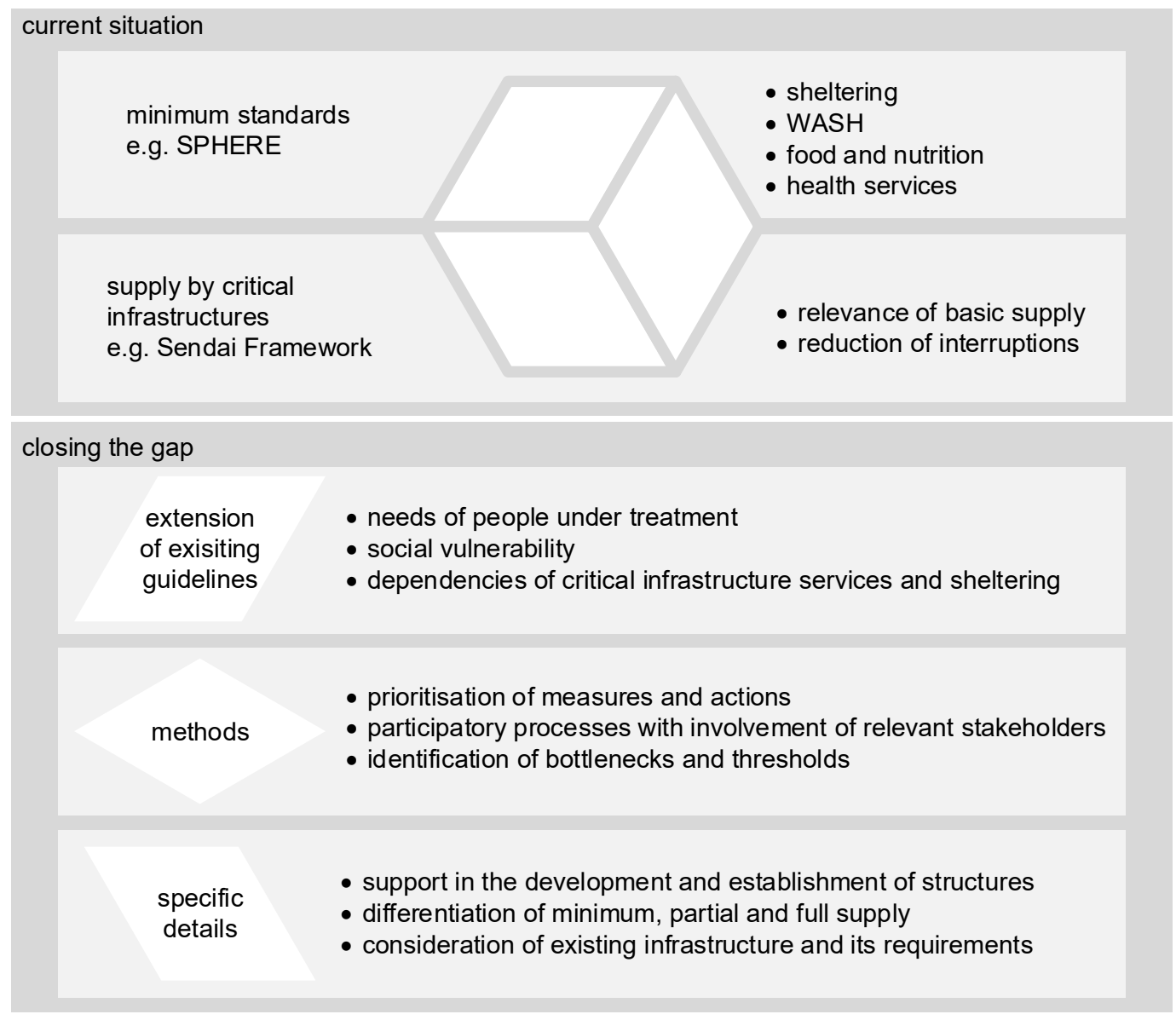

Figure 3. Findings of this article to close the identified gaps.

\section{Conclusions}

This article aims to demonstrate how a cross-cutting topic such as infrastructure can connect different fields and agendas in disaster risk research and practice; in this case, the Sendai Framework for Disaster Risk Reduction with Humanitarian Agendas, e.g., the Agenda for Humanity or the Sphere minimum standards. However, it can connect even more fields, such as the topic of sustainability in the Sustainable Development Goals, or the New Urban Agenda [89] in the field of urbanisation. In this line, it fits international calls and activities for conceptual agenda-alignment [90-92], acknowledging the limitations of conceptual considerations [93]. Therefore, integrative case studies are necessary, 
showing how an agenda-aligning topic such as critical infrastructure or basic infrastructure services can be applied for multiple settings, for instance, informal settlements or urban poverty [94-97]. Research has shown that knowledge management and coordination are often necessary to bridge separated fields $[98,99]$.

Moreover, there is a recurring division of perceiving infrastructure in its role as either a purely physical or structural component. This division runs the risk of overseeing the human role of adjustment to a hazard [100] as much as the adjustment to infrastructure failure. To mitigate the latter, the human role in being part of the infrastructure system elements must be considered. Initially, this resembles a classical definition of infrastructures [101], in which infrastructures are described as the sum of material, institutional and personnel factors. However, humans' role receded more and more and became an operational category overwhelmed by technical aspects [102,103]. It needs to be noted that this is not a topic for so-called developed societies only. It is also a topic for developing countries prone to the vulnerability paradox [53] since they become dependent on infrastructure supply provisions, so any interruption or failure can result in irreversible loss. The latter is especially true for shelters that are creating boundary spaces in which shelter residents and personnel become dependent on external supply.

Moreover, the more infrastructure services are taken for granted, the greater will be the impact once they fail. Affluence and material wealth can have mitigative but also generative influence on facets of vulnerability [104]. Maybe it is time to rethink the perpetuated gap between highly industrialised and developing countries. However, certain restrictions of comparisons must be acknowledged since it is not possible to define generally valid conclusions in the field of security research. It is always a matter of being aware of cultural, historical, legal and social differences. This article's observations and suggestions are contextual and need to be adjusted in other contexts. However, higher development means no escape from the dependency on interdependent infrastructure. Moreover, the Sphere handbook as well as the Agenda for Humanity have been written mostly for developing countries with good argumentation that there exist higher rates of poverty. Developing countries need, as compared to industrialised countries, an increase in their financial and institutional capacities. However, there is also a need for modernisation and advancement of shelter and emergency management planning in industrialised countries such as Germany. It is interesting for those countries, too, to learn from the Sphere handbook and it might be also the time to include lessons learned from industrialised countries already working with such standards in other contexts.

Author Contributions: Conceptualization, A.F., L.B., S.K.; investigation, F.N., K.T.; writing—original draft preparation A.F.; writing-review and editing, L.B., S.K., F.N., K.T.; visualization, A.F., L.B. All authors have read and agreed to the published version of the manuscript.

Funding: Parts of this research were funded by Ministry of Education and Research, Germany, grant number 13N13989.

Institutional Review Board Statement: Not applicable.

Informed Consent Statement: Not applicable.

Data Availability Statement: Data sharing not applicable.

Acknowledgments: Axel Dierich, Matthias Garschagen, Chris Hetkämper and Simone Sandholz were helpful in discussing earlier versions and we are very thankful for the intellectual input.

Conflicts of Interest: The authors declare no conflict of interest.

\section{References}

1. Degler, E.; Liebig, T.; Senner, A.-S. Integrating refugees into the Labour Market—Where does Germany Stand? ifo DICE Rep. 2017, 15, 6-10.

2. Eckhard, S.; Lenz, A.; Seibel, W.; Roth, F.; Fatke, M. Latent hybridity in administrative crisis management: The German refugee crisis of 2015/16. J. Public Adm. Res. Theory 2020, 1-18. [CrossRef] 
3. Bogumil, J.; Hafner, J.; Kastilan, A. Städte und Gemeinden in der Flüchtlingspolitik: Welche Probleme gibt es-und wie kann man sie lösen? Studie; Stiftung Mercator: Essen, Germany, 2017.

4. Auswärtiges Amt. Strategie des Auswärtigen Amts zur Humanitären Hilfe im Ausland 2019-2023; Auswärtiges Amt: Berlin, Germany, 2019; p. 60.

5. Speth, R.; Becker, E. Zivilgesellschaftliche Akteure und die Betreuung geflüchteter Menschen in deutschen Kommunen. In Opusculum; Maecenata Institut: Berlin, Germany, 2016; p. 61.

6. Greussing, E.; Boomgaarden, H.G. Shifting the refugee narrative? An automated frame analysis of Europe's 2015 refugee crisis. J. Ethn. Migr. Stud. 2017, 43, 1749-1774. [CrossRef]

7. BBK. Neue Strategie zum Schutz der Bevölkerung in Deutschland; BBK: Bonn, Germany, 2010; p. 86.

8. Hassel, A.; Wagner, B. The EU's 'migration crisis': Challenge, threat or opportunity. In Social Policy in the European Union: State of Play; European Trade Union Institute (ETUI): Brussels, Belgium, 2016; pp. 61-92.

9. United Nations. Sendai Framework for Disaster Risk Reduction 2015-2030; United Nations: Geneva, Switzerland, 2015.

10. IAEG-SDGs-Inter-Agency and Expert Group on SDG Indicators. SDG Indicators. Global Indicator Framework for the Sustainable Development Goals and Targets of the 2030 Agenda for Sustainable Development; A/RES/71/313 E/CN.3/2018/2; United Nations Statistical Commission: New York, NY, USA, 2018; p. 21.

11. Fekete, A. Common criteria for the assessment of critical infrastructures. Int. J. Disaster Risk Sci. 2011, 2, 15-24. [CrossRef]

12. Dierich, A.; Tzavella, K.; Setiadi, N.; Fekete, A.; Neisser, F. Enhanced crisis-preparation of critical infrastructures through a participatory qualitative-quantitative interdependency analysis approach. In Proceedings of the ISCRAM 2019 Conference Proceedings, ISCRAM Conference, Valencia, Spain, 19-22 May 2019.

13. Abrahams, D. The barriers to environmental sustainability in post-disaster settings: A case study of transitional shelter implementation in Haiti. Disasters 2014, 38, S25-S49. [CrossRef]

14. Davis, I. What have we learned from 40 years' experience of Disaster Shelter? Environ. Hazards 2011, 10, 193-212. [CrossRef]

15. Warner, K.; Hamza, M.; Oliver-Smith, A.; Renaud, F.; Julca, A. Climate change, environmental degradation and migration. Nat. Hazards 2010, 55, 689-715. [CrossRef]

16. Chandler, D. The road to military humanitarianism: How the human rights NGOs shaped a new humanitarian agenda. Hum. Rights Q. 2001, 23, 678-700. [CrossRef]

17. Davey, E.; Borton, J.; Foley, M. A History of the Humanitarian System: Western Origins and Foundations; Overseas Development Institute Humanitarian Policy Group: London, UK, 2013.

18. Crawley, H. Managing the unmanageable? Understanding Europe's response to the migration 'crisis'. Hum. Geogr. 2016, 9, 13-23. [CrossRef]

19. Slominski, P.; Trauner, F. How do member states return unwanted migrants? The strategic (non-) use of 'Europe'during the migration crisis. JCMS J. Common Mark. Stud. 2018, 56, 101-118. [CrossRef]

20. Achtnich, M. Shifting Shelters Migrants, Mobility and the Making of Open Centers in Malta. Structures of Protection? Rethinking Refugee Shelter; Berghahn Books: New York, NY, USA, 2020; Volume 39, p. 45.

21. Liebe, U.; Meyerhoff, J.; Kroesen, M.; Chorus, C.; Glenk, K. From welcome culture to welcome limits? Uncovering preference changes over time for sheltering refugees in Germany. PLoS ONE 2018, 13, e0199923. [CrossRef] [PubMed]

22. Eleftheriadou, M. Fight after flight? An exploration of the radicalization potential among refugees in Greece. Small Wars Insurg. 2020, 31, 34-60. [CrossRef]

23. Howden, D. Anti-Shelter and the Spectacle of Deterrence. Structures of Protection? Rethinking Refugee Shelter; Berghahn Books: New York, NY, USA, 2020; Volume 39, p. 57.

24. Jahre, M.; Persson, G.; Kovács, G.; Spens, K.M. Humanitarian logistics in disaster relief operations. Int. J. Phys. Distrib. Logist. Manag. 2007, 37, 99-114. [CrossRef]

25. Van Wassenhove, L.N. Humanitarian aid logistics: Supply chain management in high gear. J. Oper. Res. Soc. 2006, 57, 475-489. [CrossRef]

26. John, L.; Ramesh, A.; Sridharan, R. Humanitarian supply chain management: A critical review. Int. J. Serv. Oper. Manag. 2012, 13, 498-524. [CrossRef]

27. Ogata, S.; Sen, A. Human Security NOW; Commission on Human Security: New York, NY, USA, $2003 ;$ p. 159.

28. Sphere Association. The Sphere Handbook, Humanitarian Charter and Minimum Standards in Humanitarian Response, 4th ed.; Sphere Association: Geneva, Switzerland, 2018.

29. Schultz, C.H.; Koenig, K.L.; Lewis, R.J. Implications of hospital evacuation after the Northridge, California, earthquake. N. Engl. J. Med. 2003, 348, 1349-1355. [CrossRef]

30. King, R.V.; Polatin, P.B.; Hogan, D.; Downs, D.L.; North, C.S. Needs assessment of Hurricane Katrina evacuees residing temporarily in Dallas. Community Ment. Health J. 2016, 52, 18-24. [CrossRef]

31. Yun, N.Y.; Hamada, M. Evacuation behavior and fatality rate during the 2011 Tohoku-Oki earthquake and tsunami. Earthq. Spectra 2015, 31, 1237-1265. [CrossRef]

32. Escamilla, E.Z.; Habert, G. Global or local construction materials for post-disaster reconstruction? Sustainability assessment of twenty post-disaster shelter designs. Build. Environ. 2015, 92, 692-702. [CrossRef]

33. Fredriksen, A. Emergency shelter topologies: Locating humanitarian space in mobile and material practice. Environ. Plan. D Soc. Space 2014, 32, 147-162. [CrossRef] 
34. Apte, A. Humanitarian logistics: A new field of research and action. Found. Trends Technol. Inf. Oper. Manag. 2010, 3, 1-100.

35. Bouchon, S. The Vulnerability of Interdependent Critical Infrastructures Systems: Epistemological and Conceptual State-of- the-Art; Ispra: Institute for the Protection and Security of the Citizen: Rome, Italy; Joint Research Centre: Brussels, Belgium; European Commission: Brussels, Belgium, 2006.

36. Lauwe, P.; Harmon, C.; Pratt, A.; Gorka, S. The protection of critical infrastructure within Germany. In Toward a Grand Strategy against Terrorism; McGraw Hill: New York, NY, USA, 2010; pp. 328-340.

37. Seybold, J.; Hemmert-Seegers, C.; Solarek, A. Schlussbericht-Verbundprojekt: "Katastrophenschutz-Leuchttürme als Anlaufstelle für die Bevölkerung in Krisensituationen"-Teilvorhaben: Einbindung von Medizinischen Einrichtungen in das Konzept der KatastrophenschutzLeuchttürme; CHARITÉ-Universitätsmedizin: Berlin, Germany, 2016.

38. Ohder, C.; Sticher, B.; Geißler, S.; Schweer, B. Bürgernaher Katastrophenschutz aus Sozialwissenschaftlicher und Rechtlicher Perspektive. Bericht der Hochschule für Wirtschaft und Recht Berlin zum Forschungsprojekt "Katastrophenschutz-Leuchttürme als Anlaufstellen für die Bevölkerung in Krisensituationen"; Kat-Leuchttürme: Berlin, Germany, 2015; p. 36.

39. Bross, L.; Krause, S.; Wannewitz, M.; Stock, E.; Sandholz, S.; Wienand, I. Insecure security: Emergency water supply and minimum standards in countries with a high supply reliability. Water 2019, 11, 732. [CrossRef]

40. Bundesministerium des Innern. Konzeption Zivile Verteidigung (KZV); Bundesministerium des Innern: Berlin, Germany, 2016; p. 70.

41. Federal Office of Civil Protection and Disaster Assistance. Sicherheit der Trinkwasserversorgung: Teil 1: Risikoanalyse; Grundlagen und Handlungsempfehlungen für Aufgabenträger der Wasserversorgung in den Kommunen; BBK-Bundesamt für Bevölkerungsschutz und Katastrophenhilfe: Bonn, Germany, 2016.

42. Bross, L.; Wienand, I.; Krause, S. Sicherheit der Trinkwasserversorgung: Teil 2: Notfallvorsorgeplanung; Grundlagen und Handlungsempfehlungen für Aufgabenträger der Wasserversorgung in den Kommunen. In Praxis im Bevölkerungsschutz; BBK—Bundesamt für Bevölkerungsschutz und Katastrophenhilfe: Bonn, Germany, 2019.

43. Sayyed, M.A.; Gupta, R.; Tanyimboh, T. Modelling pressure deficient water distribution networks in EPANET. Procedia Eng. 2014, 89, 626-631. [CrossRef]

44. Rinaldi, S.M.; Peerenboom, J.P.; Kelly, T.K. Identifying, Understanding, and analyzing critical infrastructure interdependencies. IEEE Control Syst. Mag. 2001, 21, 11-25.

45. Pescaroli, G.; Alexander, D. Critical infrastructure, panarchies and the vulnerability paths of cascading disasters. Nat. Hazards 2016, 82, 175-192. [CrossRef]

46. Neisser, F.; Pohl, J. "Kritische Infrastrukturen" und "material turn". Eine akteur-netzwerktheoretische Betrachtung. Berichte Geogr. Landeskd. 2013, 87, 25-44.

47. US Government. The President's Commission on Critical Infrastructure Protection (PCCIP); Executive Order 13010; US Government: Washington, DC, USA, 1996.

48. Moteff, J. Risk Management and Critical Infrastructure Protection: Assessing, Integrating, and Managing Threats, Vulnerabilities and Consequences; A final report from SEMA's Assignment on Critical Societal Dependencies; Congressional Research Service, The Library of Congress: Washington, DC, USA, 2005.

49. MSB-Swedish Civil Contingencies Agency. A Summary Version of the Report: If one Goes Down—Do all Go Down? MSB-Swedish Civil Contingencies Agency: Karlstad, Sweden, 2009.

50. UNISDR. Technical Guidance for Monitoring and Reporting on Progress in Achieving the Global Targets of the Sendai Framework for Disaster Risk Reduction (New Edition); United Nations: Geneva, Switzerland, 2017; p. 179.

51. UN/ISDR. Hyogo Framework for Action 2005-2015: Building the Resilience of Nations and Communities to Disasters (HFA); United Nations UN/ISDR-Inter-Agency Secretariat of the International Strategy for Disaster Reduction: Geneva, Switzerland, 2005.

52. United Nations. Yokohama strategy and plan of action for a safer world. Guidelines for natural disaster prevention, preparedness and mitigation. In Proceedings of the World Conference on Natural Disaster Reduction, Yokohama, Japan, $23-27$ May 1994.

53. NOTA-Rathenau-Instituut. Stroomloos: Kwetsbaarheid van de Samenleving, Gevolgen van Verstoringen van de Elektriciteitsvoorziening (Blackout. Vulnerability of Society and Impacts of Electricity Supply Failure); Rathenau Instituut: The Hague, The Netherlands, 1994; p. 264.

54. Krings, S. Dear Neighbours ... A comparative exploration of approaches to managing risks related to hazardous incidents and critical infrastructure outages. Erdkunde 2018, 72, 103-124. [CrossRef]

55. André, G.; Collins, S. Raising standards in emergency relief: How useful are Sphere minimum standards for humanitarian assistance? BMJ 2001, 323, 740-742.

56. FMIG-Federal Ministry of the Interior of Germany. National Strategy for Critical Infrastructure Protection (CIP Strategy); FMIGFederal Ministry of the Interior of Germany: Berlin, Germany, 2009.

57. UN OCHA. Agenda for Humanity. Overview. Advancing the Agenda for Humanity. Agenda for Humanity Booklet; OCHA: New York, NY, USA, 2017; p. 12.

58. Bogardi, J.J. Hazards, risks and vulnerabilities in a changing environment: The unexpected onslaught on human security? Glob. Environ. Chang. 2004, 14, 361-365. [CrossRef]

59. United Nations. Human Security in Theory and Practice. Application of the Human Security Concept and the United Nations Trust Fund for Human Security; Human Security Unit, Office for the Coordination of Humanitarian Affairs, United Nations Trust Fund for Human Security: New York, NY, USA, 2009; p. 79. 
60. Van Westen, C.; Van Asch, T.W.; Soeters, R. Landslide hazard and risk zonation-Why is it still so difficult? Bull. Eng. Geol. Environ. 2006, 65, 167-184. [CrossRef]

61. Bruneau, M.; Chang, S.E.; Eguchi, R.T.; Lee, G.C.; O’Rourke, T.D.; Reinhorn, A.M.; Shinozuka, M.; Tierney, K.; Wallace, W.A.; von Winterfeldt, D. A framework to quantitatively assess and enhance the seismic resilience of communities. Earthq. Spectra 2003, 19, 733-752. [CrossRef]

62. Cutter, S.L.; Barnes, L.; Berry, M.; Burton, C.; Evans, E.; Tate, E.; Webb, J. A place-based model for understanding community resilience. Glob. Environ. Chang. 2008, 18, 598-606. [CrossRef]

63. FMIG. Protecting Critical Infrastructures-Risk and Crisis Management. A Guide for Companies and Government Authorities, 2nd ed.; Federal Ministry of the Interior of Germany: Berlin, Germany, 2011.

64. Riegel, C. Risk Assessment And Critical Infrastructure Protection In Health Care Facilities: Reducing Social Vulnerability; German Federal Service of Interior: Berlin, Germany, 2008.

65. Chan, E.Y.; Yue, J.; Lee, P.; Wang, S.S. Socio-Demographic predictors for urban community disaster health risk perception and household based preparedness in a Chinese urban city. PLoS Curr. 2016, 8. [CrossRef] [PubMed]

66. Rhein, S. Kapazitäten der Bevölkerung zur Bewältigung Eines Lang Anhaltenden Flächendeckenden Stromausfalles: Empirische Untersuchung für das Bezugsgebiet Deutschland; Bundesamt für Bevölkerungsschutz und Katastrophenhilfe: Bonn, Germany, 2013.

67. Goersch, H.G.; Werner, U. Empirical Study on the Feasibility of Measures for Public Self-Protection Capability Enhancement: Empirische Untersuchung der Realisierbarkeit von Massnahmen zur Erhoehung der Selbstschutzfaehigkeit der Bevoelkerung; Bundesamt für Bevölkerungsschutz und Katastrophenhilfe: Bonn, Germany, 2011.

68. Heagele, T.N. Lack of evidence supporting the effectiveness of disaster supply kits. Am. J. Public Health 2016, 106, 979-982. [CrossRef]

69. Ohder, C.; Röpcke, J.; Sticher, B.; Geißler, S.; Schweer, B. Relief Needs and Willingness to Help in the Event of Long-Term Power Blackout. Results of a Citizen Survey in Three Berlin Districts; Berlin School of Economics and Law: Berlin, Germany, 2014.

70. Birkmann, J.; Wenzel, F.; Greiving, S.; Garschagen, M.; Vallée, D.; Nowak, W.; Welle, T.; Fina, S.; Goris, A.; Rilling, B.; et al. Extreme events, critical infrastructures, human vulnerability and strategic planning: Emerging research issues. J. Extreme Events 2016, 3, 1650017. [CrossRef]

71. Maxwell, D. Food security and its implications for political stability: A humanitarian perspective. In Proceedings of the FAO High Level Expert Forum on Addressing Food Insecurity in Protracted Crises (FAO, Rome), Rome, Italy, 13-14 September 2012.

72. Pothiawala, S. Food and shelter standards in humanitarian action. Turk. J. Emerg. Med. 2015, 15, 34-39.

73. Urlainis, A.; Shohet, I.M.; Levy, R.; Ornai, D.; Vilnay, O. Damage in critical infrastructures due to natural and man-made extreme events-A critical review. Procedia Eng. 2014, 85, 529-535. [CrossRef]

74. Miles, S.B. Foundations of community disaster resilience: Well-Being, identity, services, and capitals. Environ. Hazards 2015, 14, 103-121. [CrossRef]

75. Bundesnetzagentur. Untersuchungsbericht über die Versorgungsstörungen im Netzgebiet des RWE im Münsterland vom 25.11.2005; Bundesnetzagentur: Bonn, Germany, 2006; p. 47.

76. Menski, U.; Gardeman, J. Auswirkungen des Ausfalls Kritischer Infrastrukturen auf den Ernährungssektor am Beispiel des Stromausfalls im Münsterland im Herbst 2005; FH Münster: Münster, Germany, 2008.

77. UCTE-Union for the Co-Ordination of Transmission of Electricity. Final Report System Disturbance on 4 November 2006; UCTEUnion for the Co-Ordination of Transmission of Electricity: Brussels, Belgium, 2007.

78. DKKV. Lessons Learned. Hochwasservorsorge in Deutschland. Lernen aus der Katastrophe 2002 im Elbegebiet; DKKV 29; DKKVDeutsches Komitee für Katastrophenvorsorge e.V.(German Committee for Disaster Reduction): Bonn, Germany, 2003 ; p. 151.

79. DKKV (Ed.) Das Hochwasser im Juni 2013. Bewährungsprobe für das Hochwasserrisikomanagement in Deutschland; DKKV-Schriftenreihe Nr. 53; DKKV e.V.: Bonn, Germany, 2005.

80. Pescaroli, G.; Kelman, I. How Critical infrastructure orients international relief in cascading disasters. J. Conting. Crisis Manag. 2017, 25, 56-67. [CrossRef]

81. Dufour, C.; de Geoffroy, V.; Maury, H.; Grünewald, F. Rights, standards and quality in a complex humanitarian space: Is Sphere the right tool? Disasters 2004, 28, 124-141. [CrossRef]

82. Saunders, G. Dilemmas and challenges for the shelter sector: Lessons learned from the sphere revision process. Disasters 2004, 28, 160-175. [CrossRef] [PubMed]

83. Davis, I.; Alexander, D. Recovery from Disaster; Routledge: Abingdon, UK; New York, NY, USA, $2015 ;$ p. 390.

84. Fan, L. Shelter strategies, humanitarian praxis and critical urban theory in post-crisis reconstruction. Disasters 2012, 36, S64-S86. [CrossRef] [PubMed]

85. Crawford, K.; Suvatne, M.; Kennedy, J.; Corsellis, T. Urban shelter and the limits of humanitarian action. Forced Migr. Rev. 2010, $34,27$.

86. Ministry of the Interior of the State of North-Rhine Westfalia. Betreuungsdienst-Konzept NRW «Betreuungsplatz-Bereitschaft 500 NRW» (BTP-B 500 NRW); Ministry of the Interior of the State of North-Rhine Westfalia: Düsseldorf, Germany, 2009 ; p. 18.

87. Garschagen, M.; Sandholz, S. The role of minimum supply and social vulnerability assessment for governing critical infrastructure failure: Current gaps and future agenda. Nat. Hazards Earth Syst. Sci. 2018, 18, 1233-1246. [CrossRef]

88. Tzavella, K.; Fekete, A.; Fiedrich, F. Opportunities provided by geographic information systems and volunteered geographic information for a timely emergency response during flood events in Cologne, Germany. Nat. Hazards 2018, 91, 29-57. [CrossRef] 
89. UN/HABITAT. New Urban Agenda; United Nations, Habitat III Secretariat: Quito, Ecuador, 2017; p. 65.

90. Van Oers, R.; Roders, A.P. Aligning agendas for sustainable development in the post 2015 world. J. Cult. Herit. Manag. Sustain. Dev. 2014, 4, 122-132. [CrossRef]

91. Clarke, M.L.; Blanchard, M.K.; Maini, R.; Radu, A.; Eltinay, N.; Zaidi, Z.; Murray, V. Knowing what we know-Reflections on the development of technical guidance for loss data for the sendai framework for disaster risk reduction. PLoS Curr. 2018, 10. [CrossRef]

92. Murray, V.; Maini, R.; Clarke, L.; Eltinay, N. Coherence between the Sendai framework, the SDGs, the climate agreement, new urban agenda and world humanitarian Summit, and the role of science in their implementation. In Proceedings of the Global Platform for Disaster Risk Reduction, Cancun, Mexico, 24-26 May 2017; pp. 5-8.

93. Wisner, B. Five years beyond Sendai-Can we get beyond frameworks? Int. J. Disaster Risk Sci. 2020, 11, 239-249. [CrossRef]

94. Bhatnagar, A.; Nanda, T.P.; Singh, S.; Upadhyay, K.; Sawhney, A.; Swamy, D.R.R. Analysing the role of India's smart cities mission in achieving sustainable development goal 11 and the new urban agenda. In Sustainable Development Research in the Asia-Pacific Region; Springer: Cham, Switzerland, 2018; pp. 275-292.

95. Mitlin, D. Finance for shelter: Recent history, future perspectives. Small Enterp. Dev. 2003, 14, 11-20. [CrossRef]

96. Narayanan, S.; Rajan, A.T.; Jebaraj, P.; Elayaraja, M. Delivering basic infrastructure services to the urban poor: A meta-analysis of the effectiveness of bottom-up approaches. Util. Policy 2017, 44, 50-62. [CrossRef]

97. Sikder, S.K.; Asadzadeh, A.; Kuusaana, E.D.; Mallick, B.; Koetter, T. Stakeholders participation for urban climate resilience: A case of informal settlements regularization in Khulna City, Bangladesh. J. Urban Reg. Anal. 2015, 7, 5-20. [CrossRef]

98. Opdyke, A.; Lepropre, F.; Javernick-Will, A.; Koschmann, M. Inter-Organizational resource coordination in post-disaster infrastructure recovery. Constr. Manag. Econ. 2017, 35, 514-530. [CrossRef]

99. Javernick-Will, A. Motivating knowledge sharing in engineering and construction organizations: Power of social motivations. J. Manag. Eng. 2012, 28, 193-202. [CrossRef]

100. White, G.F. Human Adjustment to Floods. A Geographical Approach to the Flood Problem in the United States; Research Paper No. 29; The University of Chicago: Chicago, IL, USA, 1945.

101. Jochimsen, R. Theorie der Infrastrucktur: Grundlagen der Marktwirtschaftlichen Entwicklung; Mohr Siebeck: Berlin/Heidelberg, Germany, 1966.

102. Van Laak, D. Der Begriff „Infrastruktur“ und was er vor seiner Erfindung besagte. Arch. Begr. 1999, 41, $280-299$.

103. Edwards, P.N. Infrastructure and modernity: Force, time, and social organization in the history of sociotechnical systems. Mod. Technol. 2003, 1, 185-226.

104. Eriksen, C.; Simon, G.L.; Roth, F.; Lakhina, S.J.; Wisner, B.; Adler, C.; Thomalla, F.; Scolobig, A.; Brady, K.; Bründl, M.; et al. Rethinking the interplay between affluence and vulnerability to aid climate change adaptive capacity. Clim. Chang. 2020, 162, 25-39. [CrossRef] 